\title{
POLEMIK PILKADA LANGSUNG DI MASA PANDEMI COVID-19 DALAM PRESPEKTIF SOSIOLOGI HUKUM
}

\author{
Firda Pambudi Erlambang \\ Universitas Sebelas Maret \\ E-mail: firdapambudi1998@gmail.com
}

\begin{abstract}
This study aims to examine regional head elections held in Indonesia which are carried out directly by the community as a form of democracy, besides this research also provides an overview of the conflicts that occur due to regional head elections held in Indonesia in particular. When the covid-19 virus pandemic occurred which caused turmoil in the community. The process of regional head elections in Indonesia is part of the mandate of the Constitution of the Republic of Indonesia which is carried out democratically through the general election system using the principles of direct, free, secret, honest and fair, so that the Indonesian government continues to carry out its exit from regional head elections. providing all the protection. law to respond to turmoil in society. These various problems are interesting to study in the context of sociology of law, which is part of the science to study the relationship between law and society. This research is a normative legal research which is descriptive analysis with a case and invitation approach. The results showed that there were many positive and negative impacts of direct regional elections in Indonesia and there were several obstacles in the implementation of the elections that caused social disintegration and social unrest, especially in the midst of the outbreak of this corona outbreak. so the necessary legal changes are unnecessary. invincible to people's needs.
\end{abstract}

Keywords: Election, Regional Head, Covid-19 Virus, Sociology of Law

\begin{abstract}
Abstrak
Penelitian ini bertujuan untuk mengkaji tentang pemilihan kepala daerah yang dilaksanakan di Indonesia yang dilakukan secara langsung oleh masyarakat sebagai bentuk wujud dari negara demokrasi, selain itu penelitian ini juga memberikan gambaran mengenai konflik-konflik yang terjadi akibat pemilihan kepala daerah yang dilakukan di Indonesia, terutama pada saat pandemi virus covid-19 yang menimbulkan gejolak dimasyarakat. Mengingat proses pemilihan kepala daerah di Indonesia merupakan bagian dari amanah Undang-Undang Dasar Negara Republik Indonesia yang dilakukan secara demokratis melalui sistem pemilihan umum dengan menggunakan asas langsung, umum, bebas, rahasia, jujur, dan adil maka pemerintah Indonesia tetap melaksanakan pemilihan kepala daerah dengan memberikan segala perlindungan hukum untuk menjawab gejolak dimasyarakat. Berbagai permasalahan tersebut menarik untuk dikaji dari segi sosiologi hukum yang merupakan bagian ilmu pengetahuan untuk mempelajari hubungan timbal balik antara hukum dan masyarakat. Penelitian ini merupakan penelitian hukum normatif yang bersifat diskriptif analisis dengan pendekatan perundang-undangan dan kasus. Hasil penelitian, menunjukan bahwa banyak dampak positif dan negatif akibat pemilihan kepala daerah yang dilakukan secara langsung di Indonesia serta terdapat beberapa permasalahan dalam penyelenggaraan pemilihan kepala daerah yang menimbulkan disintegritas sosial masyarakat dan gejolak sosial terutama di tengah wabah corona ini, sehingga diperlukan perubahan tatanan hukum yang disesuaikan dengan kebutuhan masyarakat.
\end{abstract}

Kata kunci : Pemilihan Umum, Kepala Daerah, Virus Covid-19, Sosiologi Hukum 


\section{A. Pendahuluan}

Isu hukum dalam penelitian ini adalah penyelenggaraan pemilihan kepala daerah di Indonesia dilihat dari sosiologi hukum yang merupakan salah satu ilmu pengetahuan yang mempelajari mengenai hubungan timbal baik antara hukum dengan gejala-gejala sosial dimasyarakat. Fokus penelitian ini, yang pertama akan membahas mengenai proses pemilihan kepala daerah di Indonesiadan yang kedua membahas mengenai pemilihan kepala daerah yang dianalisis dengan sosiologi hukum.

Pemerintah daerah merupakan salah satu alat untuk menyelenggarakan pemerintahan yang mempunyai otonomi untuk mengelola daerahnya sesuai dengan apa yang telah diatur di dalam undang-undang yang dipimpin oleh kepala daerah baik gubernur maupun bupati atau walikota dipilih melalui pemilu. Menurut Pasal 18, 18A, dan 18B Undang-Undang Dasar Negara Republik Indonesia Tahun 1945, bahwa Negara Indonesia terdiri atasdaerahdaerah provinsi dimana setiap daerah provinsi terdiri atas daerah kabupaten atau kota yang mengurus dan mengatur urusan pemerintahannya berdasarkan atas asas otonomi dan tugas pembantuan yang didalamnya terdapat pemerintahan daerah yaitu kepala daerah dan Dewan Perwakilan Rakyat Daerah (DPRD). Kemudian sebagai amanat dari UndangUndang Dasar Negara Republik Indonesia Tahun 1945 maka dibentuklah aturan lebih lanjut mengenai peraturan pemerintah daerah yang memuat mengenai pemilihan kepala daerah di Indonesia. Pilkada di Indonesia diselenggarakan berdasarkan Undang-Undang Dasar Negara Republik Indonesia Tahun 1945 dan Pancasila. Pilkada secara langsung di Indonesia dilakukan pertama kali pada Tahun 2005 berdasarkan peraturan Undang-Undang Nomor 32 Tahun 2004, kemudian mengalami perubahan yaitu Undang-Undang Nomor 9 Tahun 2015 tentang perubahan atas Undang-Undang 23 Tahun 2014 tentang Pemerintahan Daerah. Undang-undang ini memuat mengenai pemilihan kepala daerah secara demokratis yang dipilih langsung oleh rakyat melalui pilkada atau pemilihan kepala daerah. Pilkada merupakan mekanisme yang dibentuk untuk menyaring calon-calon kepala daerah yang berkompeten untuk mengisi jabatan kepala daerah provinsi maupun kabupaten atau kota yang diusung oleh partai politik, gabungan partai politik, maupun perorangan. pemilihan kepala daerah secara langsung dilakukan oleh penduduk yang secara administratif sudah memenuhi syarat untuk menggunakan hak pilihnya. Badan yang bertugas menyelenggarakan pilkada adalah Komisi Pemilihan Umum Provinsi ataupun Komisi Pemilihan Umum Kabupaten atau kota yang diawas oleh Badan Pengawas Pemilihan Umum (Bawaslu) dari provinsi maupun kabupaten. Pemilihan kepala daerah yang dilakukan secara langsung dalam rangka mewujudkan demokrasi di daerah. Pemilihan kepala daerah yang dilakukan secara langsung mengharapkan agar menciptakan kepala daerah yang akuntabel tinggi kepada masyarakat di daerah ${ }^{1}$.

Pemilihan kepala daerah secara langsung berkaitan dengan konsep dari otonomi daerah yang dimiliki oleh masing-masing daerah di Indonesia. Kebebasan daerah dalam mengambil keputusan serta mengimplementasikan sendiri merupakan hakikat dari otonomi daerah itu sendiri ${ }^{2}$. Dalam konteks otonomi daerah, seiring berjalannya waktu banyak permasalahanpermasalahan yang timbul dalam pemilihan kepala daerah di Indonesia karena memanasnya

1 Kacung Marijan, 2010, Sistem Politik Indonesia : Konsolidasi Demokrasi Pascra-Orde Baru, Jakarta : Kencana Predana Media Group, hal. 183

2 Ridho Imawan Hanafi, 2014, Pemilihan Langsung Kepala Daerah di Indonesia : Beberapa Catatan Kritis untuk Partai Politik, Jurnal Ilmu Politik Universitas Indonesia, Hal.3 
penyelenggaraan pemilu dengan munculnya pertentangan dan persaingan antara kekuatan berbagai kekuatan politik yang ikut serta dalam penyelenggaraan pemilu. Permasalahan kepala daerah terus menjadi hal yang selalu mengiringi pemilihan kepala daerah yang dilakukan Negara Indonesia yang disebabkan oleh beberapa faktor baik berasal dari KPU sendiri, masyarakat maupun dari calon kepala daerah yang kebanyakan membuat dinasti politik, yang dipetakan berupa munculnya calon tunggal yang mana calon tersebut harus melawan kotak kosong, kampanye yang tidak sesuai aturan (black campaign), politik uang atau money politic, manipulasi laporan hasil pemilu, banyaknya masyarakat yang memilih untuk golput. Mekanisme pemilihan kepala daerah yang mengalami perubahan dari tidak langsung menjadi pemilihan langsung yang menjadi alasan 'pengkhianatan' bagi rakyat karena kebanyakan kepala daerah maupun wakil kepala daerah melakukan korupsi politik serta akuntabilitas yang kurang ditegakkan karena adanya persengkokolan dari elit-elit partai baik dari pusat maupun daerah, yang akan menimbulkan ketidakpercayaan masyarakat terhadap pemilihan kepala daerah ${ }^{3}$. Sehingga demokrasi yang telah diatur sedemikian rupa dalam prosedural ini belum dilaksanakan sepenuhnya secara substansial karena masih banyak penyimpangan-penyimpangan yang terjadi pada saat pemilihan kepala daerah.

Pemilihan kepala daerah di Indonesia yang dilakukan secara serentak, selalu menimbulkan banyak problematika yang mengiringi. Terlebih lagi pilkada yang dilakukan pada tahun 2020 ini, yang mana pilkada dilakukan pada saat negara masih berjuang melawan virus covid-19. Melalui Peraturan Perundang-Undangan Nomor 2 Tahun 2020 tentang Perubahan Ketiga atas Undang-Undang Nomor 1 Tahun 2015 tentang Penetapan Peraturan Pemerintah Pengganti Undang-Undang Nomor 1 Tahun 2014 tentang Pemilihan Gubernur, Bupati dan Walikota Menjadi Undang-Undang, dengan peraturan perundang-undang ini pemerintah tetap mengadakan pemilihan kepala daerah yang diselenggarakan pada 9 Desember 2020. Pilkada yang dilakukan ditengah-tengah masa pandemi ini tentunya akan menimbulkan berbagai pro dan kontra di masyarakat, karena penyelenggaraan ini dianggap sebagai sesuatu yang dipaksakan mengingat kasus ini terus menaik jumlahnya dari hari kehari. Dari hasil pilakada yang dilaksanakan, Mahkamah Konstitusi telah menerima sebanyak 135 permohonan perselisihan hasil pilkada sejak pengumuman atas hasil pleno dari KPU disejumlah daerah yang disebabkan oleh beberapa faktor, biasanya pasangan calon kepala dan wakil kepala daerah menemukan kecurangan pada saat pelaksanaan pilkada. Permohonan ini diprediksi akan terus meningkat, mengingat waktu pengajuan permohonan sengketa hasil pemilu dibuka pada 16 Desember 2020 sampai 5 Januari 2021 untuk provinsi dan tanggal 13 Desember 2020 sampai 5 Januari $2020^{4}$. Hal tersebut terbukti bahwa masyarakat belum sepenuhnya menerima pemilihan kepala daerah yang ada di Indonesia karena banyaknya pelanggaran yang dilakukan oleh kepala daerah maupun wakil kepala daerah.

Calon kepala daerah maupun wakil kepala daerah pada saat mencalonkan diri harus memenuhi persyaratan sesuai dengan peraturan perundang-undangan agar menciptakan calon yang akuntabel dan dapat mengatur daerahnya masing-masing. Hal tersebut penting dilakukan mengingat dari pemikiran Chambaliss dan Seidman SEBAGAIMANA DIKUTIP H DJUARI bahwa suatu peraturan dapat berjalan efektif atau tidak hanya dilihat dari

3 Suyatno, 2016, Politik Indonesia, Jurnal Unnes, Vol. 1, No. 2, hal. 213

4 Edi Suwiknyo, 2020, 135 Calon Kepala Daerah Gugat Hasil Pilkada, KPU Perlu di evaluasi?, Bisnis.com, diakses pada 18 Desember 2020, pukul 17:00 
peraturannya itu sendiri, tetapi juga dilihat dari faktor-faktor lainnya yaitu faktor sosial maupun faktor personalnya ${ }^{5}$. Berbagai fenomena pemilihan kepala daerah menarik untuk dikaji dari segi sosiologi hukum. sosiologi hukum dapat mengkaji mengenai hubungan timbal balik antara hukum dengan masyarakat serta segala gejala-gejala sosial yang ada di dalam masyarakat mengenai pemilihan kepala daerah yang selama ini dilakukan oleh daerah-daerah di Indonesia melalui pemilihan secara langsung oleh masyarakat. Hukum atau peraturan yang kurang efektif dimasyarakat pada saat pesta demokrasi karena dipengaruhi oleh faktor sosiologis baik dari masyarakat, partai politik maupun pemilihnya sendiri. Gejala sosial yang terjadi dimasyarakat merupakan suatu proses dari pesta demokrasi terjadi secara berkala di setiap daerah di Indonesia agar dapat menentukan pemimpin yang dapat memberikan kesejahteraan, kemakmuran dan mengembangkan daerahnya.

Tujuan penelitian ini adalah memberikan gambaran mengenai problematika yang terjadi pada saat pemilihan kepala daerah di Indonesia, terlebih pada saat masa pandemi virus covid-19 yang masih membayangi Bangsa Indonesia. Namun, pemerintah tetap melaksanakan pemilihan tersebut dengan alasan bahwa kita tidak tahu sampai kapan virus ini akan berakhir serta mencegah terjadinya kekosongan kekuasaan di berbagai daerah di Indonesia. Permasalahan tersebut akan dikaji dan dianalisis dengan sosiologi hukum agar dapat mempelajari segala pelanggaran dan hambatan yang timbul dimasyarakat, sehingga akan ditemukan alternatif penyelesaiannya. Penelitian ini diharapkan mampu memberikan penyelesaian atas permasalahan yang terjadi agar terjadi singkronisasi antara hukum dengan gejala-gejala sosial dimasyarakat yang timbul pada saat pemilihan kepala daerah di Indonesia.

\section{B. Pembahasan}

\section{Pemilihan Kepala Daerah di Indonesia}

Undang-Undang Dasar Negara Republik Indonesia Tahun 1945 dalam Pasal 18 menyatakan bahwa Negara Indonesia terdiri atas daerah-daerah provinsi dan setiap provinsi terdiri atasa kabupaten atau kota dimana masing-masing provinsi, kabupaten atau kota mempunyai pemerintah daerah yang diatur dengan undang-undang. Pemerintah daerah terdiri atas kepala daerah dan wakil kepala daerah serta Dewan Perwakilan Rakyat Daerah di masing-masing provinsi dan kabupaten atau kota, yang dipilih melalui pemilihan umum secara demokratis. Pemilihan kepala daerah dan wakil kepala daerah berdasarkan pada Pasal 1 ayat (1) Peraturan Pemerintah Republik Indonesia Nomor 6 Tahun 2005 tentang Pemilihan, Pengesahan, Pengangkatan dan Pemberhentian Kepala Daerah dan Wakil Kepala Daerah junto Peraturan Pemerintah Nomor 49 Tahun 2008 tentang perubahan atas Peraturan Pemerintah Nomor 6 Tahun 2005 merupakan saran untuk melaksanakan kedaulatan rakyat di wilayah provinsi atau kabupaten berdasarkan atas Pancasila dan Undang-Undang Dasar Negara Republik Indonesia Tahun 1945 untuk memilih kepala daerah dan wakil kepala daerah. Berdasarkan pada Pasal 56 ayat (1) Undang-Undang Nomor 9 Tahun 2015 tentang perubahan atas Undang-Undang 23 Tahun 2014 tentang Pemerintahan Daerah menjelaskan bahwa pelaksanaan pemilihan kepala daerah dan wakil kepala daerah dilakukan secara demokratis yang berdasarkan pada asas langsung, umum, bebas, rahasia, jujur, dan adil. Pasal 56 ayat (2) menjelaskan bahwa kepala daerah dan wakil kepala daerah yang ingin

5 H. Djuari, 2011, Problematika Pemiliha Kepala Daerah Secara Langsung (dalam Prespektif Sosiologis), Jurnal Dinamika Hukum Unissula Semarang, hal.32 
mencalonkan diri harus diajukan oleh partai politik maupun gabungan dari partai politik. Namun, ketentuan tersebut tidak mempunyai kekuatan hukum mengikat setelah ada calon kepala daerah dari Nusa Tenggara Barat yang mengajukan pengujian terhadap UndangUndang Nomor 23 Tahun 2004 ke Mahkamah Konstitusi yang berkaitan dengan ketentuan dimana hanya memberikan kesempatan kepada partai politik maupun gabungan dari partai politik saja yang dapat mencalonkan diri sebagai kepala maupun wakil kepala daerah. setelah itu Mahkmah Konstitusi mengabulkan permohonan tersebut dan memberikan kesempatan bagi calon perseorangan untuk dapat maju sebagai calon kepala dan wakil kepala daerah yang mana diatur di dalam Undang-Undang Nomor 12 Tahun 2008 tentang perubahan kedua atas Undang-Undang Nomor 32 Tahun 2004 tentang Pemerintahan Daerah ${ }^{6}$.

Pemilihan kepala daerah di Indonesia telah mengikuti berbagai sistem sejak jaman kemerdekaan, terbukti mengenai mekanisme pengisian jabatan kepala dan wakil kepala daerah telah dilakukan dalam empat sistem, antara lain ${ }^{7}$ :

1. Menggunakan sistem penunjukan dan pengangkatan oleh pusat, ini terjadi pada saat masa penjajahan Belanda dan Jepang yang dijelaskan dalam Undang-Undang Nomor 27 Tahun 1902. Setelah kemerdekaan pemerintah Indonesia menggunakan sistem penunjukan terhadap kepala dan wakil kepala daerah berdasarkan atas Undang-Undang Nomor 1 Tahun 1945, Undang-Undang Nomor 22 Tahun 1948, dan Undang-Undang Nomor 1 Tahun 1957.

2. Sistem penunjukan, sistem ini digunakan dengan berdasarkan pada penetapan presiden Nomor 6 Tahun 1959 jo Penetapan Presiden Nomor 5 Tahun 1960, Undang-Undang Nomor 6 Tahun 1956, dan Undang-Undang Nomor 18 Tahun 1956 atau dikenal sebagai era dekrit presiden. Sistem pemilihan ini disebut juga sebagai sistem penunjukan dengan sistem yang memaksa karena calon bakal kepala dan wakil kepala daerah yang ditunjuk harus mengindahkan amanat yang diberikan.

3. Sistem pemilihan dengan menggunakan sistem perwakilan. Sistem ini merupakan sistem pemilihan kepala daerah dan wakil kepala daerah yang dilakukan oleh DPRD, setelah DPRD menunjuk calon kepala dan wakil kepala daerah maka selanjutnya presiden akan menentukan calon yang akan terpilih. Hal tersebut merupakan bentuk perwujudan dari Undang-Undang Nomor 5 Tahun 1974.

4. Menggunakan sistem pemilihan perwakilan. Sistem ini berdasarkan atas UndangUndang Nomor 18 Tahun 1965 dan Undang-Undang Nomor 22 Tahun 1999. Sistem pemilihan ini, kepala daerah dipilih oleh DPRD tanpa ada pengaruh dari pemerintah pusat.

5. Sistem pemilihan secara langsung oleh rakyat. Hal tersebut tertuang dalam UndangUndang Nomor 32 Tahun 2004 jo Undang-Undang Nomor 12 Tahun 2008 yang mana kepala dan wakil kepala daerah dipilih langsung oleh rakyat melalui pemilu.

Maraknya pemilihan kepala daerah yang dilakukan secara serentak di berbagai daerah Indonesia, pada masa Presiden Susilo Bambang Yudhoyono pada penghujung masa jabatannya, tepatnya pada 30 September 2014 menerbitkan Undang-Undang Nomor 22

6 Lihat putusan Mahkamah Konstitusi dalam Nomor 5/PUU-V/2007 perihal Pengujian Undang-Undang Nomor 32 Tahun 2004 tentang Pemerintah Daerah.

7 Retno Saraswati, 2011, Calon Perseorangan : Pergeseran Paradigma Kekuasaan dalam Pemilukada, Jurnal MasalahMasalah Hukum, hal.197 
Tahun 2014, dimana undang-undang tersebut mengamanatkan untuk mengembalikan mekanisme pemilihan kepala daerah kepada DPRD. Pemilihan yang dilakukan oleh DPRD atau pemilihan yang dilakukan secara tidak langsung, mempunyai dampak positif jika dilihat dari pembiayaan pemilihan kepala daerah yang mana Komisi Pemilihan Umum tidak perlu menyelenggarakan pemilihan sehingga akan menghemat waktu. Namun, pemilihan kepala daerah yang dilakukan secara tidak langsung juga akan menimbulkan sisi negatifnya, dimana partai pemenang belum otomatis menang saat mengusung kepala daerah apalagi tidak ada suara mayoritas daro DPRD. Sehingga dikhawatirkan akan berpotensi untuk terjadinya money politic karena calon kepala daerah dapat membeli suara yang diinginkan kepada DPRD. Terjadinya ketidaksesuaian antara keinginan masyarakat dan para elit politik karena rakyat tidak bisa ikut serta dalam pemilihan kepala daerah yang sepenuhnya ada ditangan DPRD, maka suara-suara aspirasi dari masyarakat akan sangat mudah untuk diabaikan ${ }^{8}$. Akan tetapi hadirnya undang-undang tersebut mendapatkan banyak penolakan dari rakyat Indonesia karena tidak sesuai dengan demokrasi yang telah disepakati sebelumnya. Sehingga pada masa Presiden Joko Widodo melalui Undang-Undang Nomor 1 Tahun 2015 mengamantkan untuk mengembalikan pemilihan kepala daerah melalui sistem demokrasi, dimana pemilihan dipilih langsung oleh rakyat ${ }^{9}$. Undang-undang ini juga merupakan titik awal dari era pilkada serentak di Indonesia, yang sebelumnya pilkada dilaksanakan pada tahun yang sama tetapi pelaksanaannya tidak dilakukan pada tanggal atau bulan yang sama pada setiap daerahnya.

Pemilihan kepala daerah yang dilakukan secara langsung merupakan sebuah amanah dari gerakan reformasi pada tahun 1998. Perlunya aspirasi dan partisipasi dari masyarakat agar terlibat langsung dalam proses pemilihan kepala daerah merupakan sebuah peristiwa demokrasi penting bagi Bangsa Indonesia karena pemilihan kepala daerah bukan merupakan suatu mekanisme untuk memilih kepala daerah dan wakil kepala daerah yang dilakukan oleh masyarakat saja, tetapi juga merupakan sebuah implementasi nyata dalam menerapkan nilai-nilai demokrasi demi mengembangkkan partisipasi dan respon dari masyarakat secara langsung ${ }^{10}$. Persoalan yang mendasar mengenai pemilihan kepala daerah di Indonesia adalah mengenai pemaknaan atas arti demokrasi itu sendiri, dimana terjadi perdebatan bahwa pemilihan secara langsung dapat dimaknai sebagai demokrasi yang sebenarnya. Namun, juga ada yang berpendapat lain bahwa pemilihan secara tidak langsung juga dikatakan sebagai demokrasi. Menurut Robert Dahl, menyatakan bahwa parameter demi mewujudkan demokrasi antara lain adalah pemilihan umum, terjadinya rotasi kekuasaan, sistem perekrutan yang dilakukan secara terbuka serta adanya akuntabilitas dari penyelenggara terhadap publik ${ }^{11}$. Walaupun pemilihan secara langsung dianggap lebih demokratis dari pada pemilihan kepala daerah secara tidak langsung, tetapi pemilihan secara tidak langsungpun dapat dikatakan sebagai pemilihan yang demokratis, asalkan dilakukan dengan proses demokratis ${ }^{12}$.

Pilkada yang dilakukan secara langsung juga merupakan bagian dari terobosan politik yang berimplikasi secara langsung terhadap daerah dan masyarakat daerah demi

8 Teten Jamaludim, 2019, Pilkada Langsung : Kisah Sukses dan Problematika, Jurnal Politik Walisongo, hal. 30

9 Topan Yuniarto, 2020, Pilkada Langsung Serentak: Sejarah dan Perkembangannya di Indonesia, Kompas Pedia.

10 Suyatno, 2016, Pemilihan Kepala Daerah dan Tantangan Demokrasi Lokal di Indonesia, Jurnal Unnes Vol. 1 No. 2, hal. 212

11 Saukani HR,dkk, 2002, Otonomi Daerah dalam Negara Kesatuan, Yogyakarta : Pustaka Pelajar, hal. 12-13

12 Leo Agustino, 2009, Pilkada dan Dinamika Politik Lokal, Yogyakarta : Pustaka Pelajar, hal. 79 
mewujudkan demokrasi yang ada didaerah tersebut. Sebab, pilkada merupakan suatu proses penguatan demokrasi demi mewujudkan tatanan pemerintah yang baik dan efektif sesuai dengan cita-cita dan harapan masyarakat maupun negara itu sendiri. Pilkada yang dilakukan secara langsung merupakan sebuah realisasi dari prinsip-prinsip demokrasi yang menjamin kebebasan individu serta mengakui persamaan derajat setiap masyarakat dalam hak pilihnya $^{13}$, serta memiliki korelasi yang erat dengan pelaksanaan kedaulatan rakyat karena dengan adanya pemilhan kepala daerah secara langsung akan memberikan kesempatan bagi masyarakat untuk memilih calon kepala daerah dan wakil kepala daerah sesuai dengan kehendak serta hati nurani masing-masing individu, sehingga akan memberikan jalinan erat antara rakyat dengan bakal calon kepala dan wakil kepala daerah yang memberikan dorongan demi terselenggaranya hubungan yang harmonis dan pemerintahan yang demokratis serta partisipatif. Sistem pemilihan kepala daerah menimbulkan beberapa dampak posisitif dan negatif di segala sisi bidang kehidupan. Dampak positif dilakukannya pemilihan kepala daerah secara langsung antara lain adalah ${ }^{14}$ :

1. Kepala daerah yang terpilih akan mempunyai legitimasi dan mandat yang sangat kuat.

2. Kepala daerah yang terpilih dalam proses pemilihan umum yang diselenggarakan oleh KPU tidak perlu memiliki keterikatan pada konsesi dari partai-partai politik maupun fraksi-fraksi partai politik.

3. Sistem pemilihan kepala daerah yang dilakukan secara langsung lebih memberikan akuntabilitas.

4. Sistem pengawasan check and balances antara badan legislatif dan eksekutif akan menjadi lebih seimbang pada saat pemilihan secara langsung.

5. Pemilihan kepala daerah secara langsung dapat memberikan kesempatan bagi masyarakat untuk memilih secara langsung terhadap calon kepala dan wakil kepala daerah yang dikehendaki sesuai dengan kriteria masing-masing individu.

Dari dampak positif yang diberikan, pemilihan kepala daerah secara langsung juga menimbulkan berbagai kelemahan-kelemahan sebagai berikut :

1. Pada saat pemilihan kepala daerah yang dilakukan secara serentak di Indonesia, tentu saja akan memerlukan biaya yang cukup banyak. Demi terselenggaranya pemilu yang demokratis tentunya membutuhkan sarana dan prasarana demi kebutuhan operasional, keamanan, dan logistik baik untuk petugas maupun masyarakat. Dana yang besar diluncurkan untuk memenuhi segala kebutuhan pada saat penyelenggaraan pemilihan kepala daerah. Seperti halnya di tahun 2020, Negara Indonesia menyelenggarakan pemilihan kepala daerah baik provinsi maupun kabupaten ditengah pandemi virus corona yang sangat berbahaya. Demi terciptanya keselamatan dan kenyamanan petugas dan masyarakat pada saat berlangsungnya pesta demokrasi lima tahunan ini, tentunya membutuhkan banyak sarana dan biaya yang tidak sedikit. Menteri Keuangan, Sri Mulyani menyatakan bahwa terjadi pembengkakan biaya pilkada di tahun 2020 ini yang mencapai $\mathrm{Rp} 20,4$ triliun yang semula hanya dirancang sebesar Rp 15,23 triliun. Hal tersebut terjadi karena harus menyediakan keperluan demi menjaga protokol

13 R. Siti Zuhro,dkk, 2011, Model Demokrasi Lokal, Jakarta : PT. HTC Mandiri, hal. 23-24

14 Nopyandari, 2011, Pemilihan Kepala Daerah yang Demokratis dalam PrespektifUndang-Undang Dasar Negara Kesatuan Republik Indonesia Tahun 1945, Jurnal Ilmu Hukum, Vol. 1, No. 2, hal. 4-5 
kesehatan pada saat pemilu dilakukan ${ }^{15}$. Besarnya dana yang harus disiapkan demi terselenggaranya pemilihan kepala daerah yang dilakukan secara langsung bukan merupakan beban yang harus ditanggung bagi calon kepala daerah dan wakil kepala daerah serta partai politik yang mengusung calonnya, tetapi juga merupakan bagian dari beban tanggung jawab negara. Selain itu, pemilihan kepala daerah secara langsung memberikan kemungkinan bagi para elit ekonomi untuk menduduki jabatan kepala daerah, karena atas dasar kemampuan finansial yang dimiliki maka mereka dapat masuk ke dalam kursi kepemimpinan bukan berasal dari tokoh-tokoh yang kompeten untuk membawa daerahnya lebih baik lagi ${ }^{16}$.

2. Memberikan peluang munculnya konflik bagi para elit dan masyarakat. Konflik tersebut terjadi karena adanya perbedaan suara dari masyarakat menimbulkan sebuah perpecahan serta disebabkan karena calon kepala daerah dapat memobilisasi pendukungnya agar terus mendukung dan berkampanye demi tercapainya target suara pada saat pilkada ${ }^{17}$.

Dari berbagai polemik mengenai pilkada secara langsung, sebenarnya pemilihan kepala daerah yang sekarang dilakukan secara langsung merupakan sebuah harapan bagi rakyat Indonesia demi mewujudkan kedaulatan rakyat karena rakyat dapat memilih secara langsung, sehingga akan memunculkan calon-calon kepala daerah yang berkualitas menurut rakyat Indonesia. Pemilihan kepala daerah yang dilakukan secara langsung juga memberikan peran penting bagi perkembangan disuatu daerah terutama demi mewujudkan keberhasilan otonomi daerah, dimana peran pemerintah terutama kepala daerah yang menjadi pokok pada sistem pemerintah daerah akan menjadi penentu untuk pembangunan dan kemajuan di daerahnya ${ }^{18}$. Aspirasi dari masyarakat juga merupakan bagian dari kehidupan demokrasi yang mana rakyat memilih calon kepala daerah berdasarkan kehendak dan hati nuraninya agar tercipta kesejahteraan di masyarakat seluruhnya.

\section{Analisis Pemilihan Kepala Daerah pada Masa Pandemi Covid-19 dalam Aspek Sosiologi Hukum}

Penyebaran virus corona atau sering disebut dengan covid-19 terus meningkat secara signifikan dari masa ke masa, tanpa terkecuali di Indonesia yang terdampak virus berbahaya ini. Pandemi ini secara masif memberikan dampak langsung terhadap berbagai sisi bidang kehidupan tanpa terkecuali pada sistem ketatanegaraan, dimana terjadi banyak penundaan berbagai agenda yang terlah direncanakan sebelumnya oleh pemerintah, termasuk agenda lima tahunan pemilihan kepala daerah di berbagai daerah Indonesia. Saat itu dengan berbagai pertimbangan, KPU mengeluarkan Surat Keputusan Nomor 179/ PL.02-Kpt/01/KPU/III/2020 tentang Penundaan Tahapan Pemilihan Gubernur dan Wakil Gubernur, Bupati dan Wakil Bupati atau Wali Kota dan Wakil Wali Kota Tahun 2020. Keputusan tersebut secara garis meliputi penundaan pelantikan panitia pemungutan suara, verifikasi syarat dukungan calon perseorangan, pembentukan panitia pemuktahiran data pemilih, serta pemuktahiran dan penyusunan daftar pemilih. Hal tersebut berdasarkan pada

15 Hadijah Alaydrus, 2020, Ini Catatan Terakhir Dana Pilkada 2020 dari Sri Mulyani, ekonomi.bisnis.com, diakses pada yanggal 28 Desember 2020, pukul 20:21

16 Amarudi dan A. Zaini Bisri, 2006, Pilkada Langsung : Problematika dan Prospek, Yogyakarta : Pustaka Pelajar, hal. 30

17 Richard S. Katz and William, 2006, Handbook of Party Politics, London : Sage Publocations, hal.90

18 Marso, 2002, Susunan dalam Satu Naskah Undang-Undang Dasar Tahun 1945 dengan perubahan-perubahannya, Jakarta : Eko Jaya, hal.2 
Peraturan Perundang-Undangan Nomor 10 Tahun 2016 tentang Perubahan Kedua atas Undang-Undang Nomor 1 Tahun 2015 tentang Pemilihan Gubernur, Bupati, dan Walikota, yang mana jika dalam keadaan memaksa dan memungkinkan ada penundaan tahapan penyelenggaraan pemilihan kepala daerah yang harus ditunda makan akan dilakukan pemilihan lanjutan dan pemilihan susulan ${ }^{19}$. Namun, Presiden Joko Widodo memberikan arahan bahwa penyelenggaraan pemilihan kepala daerah pada Tahun 2020 harus tetap dilaksanakan dengan pertimbangan bahwa kita tidak tahu kapan wabah ini akan berakhir, oleh karena itu penyelenggaraan pemilu harus dilaksanakan dengan tetap menjalankan protokol kesehatan ditatanan new normal saat ini ${ }^{20}$. Dengan diterbitkan Undang-Undang Nomor 6 Tahun 2020 tentang Penetapan Peraturan Perundang-Undangan Nomor 2 Tahun 2020 tentang Perbuahan Ketiga Undang-Undang Perundang-Undangan Nomor 10 Tahun 2016 tentang Perubahan Kedua atas Undang-Undang Nomor 1 Tahun 2015 tentang Pemilihan Gubernur, Bupati, dan Walikota ,menjadi bentuk respon pemerintah dalam pelaksanaan pilkada ditengan wabah covid-19. Pemilhan kepala daerah pada saat pandemi yang masih berlangsung, tentunya menimbulkan kekhawatiran dimasyarakat. Seperti yang terjadi diberbagai daerah di Indonesia, pasca pemilukada terjadi lonjakan pada kasus covid-19 ini, berdasarkan pada data percepatan penanganan Covid-19 di Indonesia terjadi peningkatan kasus positif sejumlah 7.354 kasus, jumlah tersebut meningkat sekitar empat kali lipat dari jumlah sebelum diadakan pilkada serentak di Indonesia ${ }^{21}$.

Dalam hal ini dibutuhkan pengendalian untuk mengatasi permasalahn yang ada, salah satunyaa dengan pemecahan melalui pendekatan sosiologi hukum yang digunakan untuk mengatasi dan menganalisis problematika yang timbul pada saat pemilihan kepala daerah di Indonesia, terlebih di masa pandemi covid-19 ini. Sosiologi hukum yang merupakan salah satu cabang ilmu pengetahuan dimana ilmu-ilmu sosial dituangkan didalam hukum di masyarakat. Sosiologi hukum merupakan bentuk dari aksi raksi di mayarakat dengan melihat hukum tidak hanya pada law in the book saja, tetapi juga melihat law in action juga, yang mana tetap mengedepankan rasa untuk mencapai keadilan hukum. Soerjono Soekanto ${ }^{22}$ menjelaskan bahwa sosiologi hukum merupakan ilmu pengetahuan yang secara analitis dan secara empiris menganalisis dan mempelajari hubungan timbal balik antara hukum dengan nilai-nilai yang tumbuh dan berkembang dimasyarakat. Sehingga sosiologi hukum memandang bahwa hukum dianggap sebagai proses untuk memahami gejala sosial yang ada dimasyarakat.

Sosiologi hukum memandang bahwa terdapat beberapa permasalahan yang muncul dalam proses pemilihan kepala daerah maupun di dalam masyarakat, antara lain adalah perilaku pemilih, dimana rentan usia pemilih juga menentukan pada saat memilih calon kepala daerah. usia yang muda atau usia pemilih pemula masih mudah untuk dipengaruhi dan tidak mempunyai rasa kepedulian mengenai pemilihan umum, bahkan mereka akan cenderung anarkis karena belum mempunyai pemikiran yang dewasa untuk menyaring mana yang baik dan mana yang buruk. Sedangkan pemilih yang sudah dewasa akan lebih mampu mengelola perbedaan-perbedaan sehingga tidak akan terprovokasi oleh calon-calon,

19 Teguh Imam Satiyono, 2020, Urgensi Perpu Pilkada di Masa Pandemi Covid-19, Webinar Nasional Forum Masyarakat, Universitas Widya Mataram

20 https://www.jogloabang.com/pustaka/uu-6-2020-perppu-2-2020-perubahan-ketiga-uu-1-2015-pilkada-serentak, diakses pada 28 Desember 2020, pukul 21:23

21 https://www.bbc.com/indonesia/indonesia-55321183, diakses pada 28 Desember 2020, pukul 21:33

22 Soerjono Soekanto, 1988, Pokok-Pokok Sosiologi Hukum,Jakarta : PT. Raja Grafindo Perkasa, hal. 6 
mereka cenderung akan memilih sesuai hati nurani mereka dengan mempertimbangkan segala aspek yang ada di dalam calon kepala dan wakil kepala daerah. Terakhir adalah usia tua, dimana rentan usia ini cenderung tidak mendapatkan pendidikan politik dan pengetahuan secara luas karena faktor usia mereka, kebanyakan mereka riskan untuk mendapatkan aliran dana dari calon-calon atau money politic sebagai upaya kampanye kepada masyarakat. Selain usia pemilih, faktor lain adalah masyarakat tidak tahu mengenai pemimpin dan bagaimana kepemimpinannya karena kurangnya pendekatan antara calon dengan masyarakat ${ }^{23}$.

Hal tersebut akan menimbulkan gejolak-gejolak sosial yang berujung pada konflik. Sosiologi hukum memandang konflik sebagai hal yang bertujuan untuk menghancurkan satu sama lain atau sebagai proses untuk merebutkan suatu posisi, kedudukan, ataupun harta benda. Terjadinya konflik di dalam pemilihan kepala daerah, dari segi sosiologis sendiri dapat disebabkan oleh beberapa faktor antara lain karena banyaknya jumlah calon kepala dan wakil kepala daerah serta partai politik yang mengusungnya, rendahnya kualitas pemimpin yang berakibat pada tindakan yang tidak sesuai dengan yang diharapkan oleh masyarakat, benturan dari kepentingan politik, serta tingkat pendidikan yang rendah sehingga tidak mengetahi sepenuhnya bagaimana menilai calon kepala daerah ${ }^{24}$. Gejalagejala yang timbul akibat pemilihan kepala daerah merupakan bentuk perubahan gejala sosial yang ada di masyarakat karena masyarakat akan menjadi semakin apatisme terhadap hak pilihnya dimana masyarakat memilih untuk golput (golongan putih )atau tidak memilih calon yang ditawarkan di dalam pemilihan umum. Golput yang terjadi dimayarakat dapat disebabkan oleh beberapa faktor yaitu karena calon dianggap tidak mempunyai kapasitas oleh masyarakat, calon dianggap tidak atau belum memberikan perubahan-perubahan dalam segala bidang di daerahnya, mayarakat belum mengenal calon pasangan karena kurangnya sosialisasi kepada mayarakat, serta anggapan bahwa banyaknya KPUD (Komisi Pemilihan Umum Daerah) yang tidak profesional karena memihak salah satu calon pasangan. Permasalahan yang timbul akibat pemilihan kepala daerah bertolak belakang dengan tujuan demokrasi Bangsa Indonesia, keadilan, serta kesejahteraan sosial yang dapat menimbulkan disentegrasi sosial akibat konflik yang timbul ditengah-tengah masyarakat pada saat euforia pemilihan kepala daerah.

Terlebih dalam ketentuan Undang-Undang Nomor 22 Tahun 2014, yang menyatakan bahwa pemilihan kepala daerah di Indonesia, sebelumnya dilakukan oleh DPRD. Namun, banyaknya desakan dari masyarakat pemerintah melakukan pemilihan secara langsung sebagaimana tertuang di dalam Undang-Undang Nomor 1 Tahun 2015 tentang Penetapan Peraturan Pemerintah Pengganti Undang-Undang Nomor 1 Tahun 2014 tentang Pemilihan Gubernur, Bupati, dan Walikota menjadi Undang-Undang merupakan suatu proses untuk memilih dan menentukan kepala daerah melalui sistem pemilihan umum oleh rakyat dengan berdasarkan atas asas langsung, umum, bebas, rahasia, jujur, dan adil. Dalam pemilihan kepala daerah, seorang calon pasangan kepala dan wakil kepala daerah diusulkan melalui partai politik ataupun gabungan dari partai politik, sehingga peran partai politik pada saat proses ini sangat besar. Pilkada yang dilakukan kan secara langsung merupakan sebuah perubahan alternatif untuk meningkat partisipasi masyarakat dan memperkuat

23 Syafri Hariansah, 2018, Analisis Pilkada dalam Prespektif Sosiologi Hukum, Tesis Program Pascasarjana Universitas Indonesia, hal. 87

24 Komarudin Sahid, 2011, Memahami Sosiologi Politik, Bogor : Ghalia Indonesia, hal. 34 
tatanan demokrasi di Indonesia. Perubahan proses pemilihan kepala daerah disebabkan karena desakan dari masyarakat, jika dilihat dari prespektif sosiologi hukum maka terjadi perubahan sosial yang dapat berpengaruh pada hukum yang berlaku.

Hukum yang kebanyakan bersifat statis akan memberikan ketidakmampuan dalam memberikan permasalahan-permasalahan pada saat terjadi konflik sosial yang memanas dimasyarakat akibat pemilihan kepala daerah. kondisi tersebut tentunya membutuhkan pemecahan yang bersifat dinamis untuk memberikan pemecahan terhadap permasalahan yang ada. Proses dinamis tersebut dibangun melalui disiplin sosiologi hukum yang diterapkan dilapangan. Sosiologu hukum dapat meneliti berbagai permasalahan yang berasal dari masyarakat maupun dari calon kepala dan wakil kepala daerah itu sendiri, gejala sosial yang terjadi akibat pilkada akan menimbulkan perpecahan sosial dimasyarakat. Sebagai contoh, seperti permasalahan pilkada yang terjadi di daerah Tolikora Papua pada Tahun 2017, pilkada tersebut telah menimbulkan gangguan terhadap keamanan di Papua. Akibat konflik tersebut menyebabkan 11 orang meninggal dan 201 orang luka-luka akibat bentrok yang disebabkan karena dugaan provokator yang membakar amarah sehingga menyebabkan konflik, berujung pada pembunuhan, penganiayaan, pembakaran rumah, dan menggunakan senjata berupa senapan angin ${ }^{25}$. Segala konflik yang terjadi pada saat pemilihan kepala daerah disebabkan karena adanya ketidakselarasan tujuan, perbedaan pendapat, perbedaan antara yang dijanjikan oleh calon kepala daerah dengan kenyataan yang dilakukan pada saat sudah menjabat, sehingga akan berdampak pada penilaian masyarakat dan kualitas kepemimpinan.konflik-konflik tersebut terjadi juga karena belum efektifnya penegakan peraturan undang-undang bahkan undang-undang yang berlaku tidak sesuai dengan kondisi masyarakat, sehingga peraturan undang-undang yang dibentuk harus memberikan gambaran bahwa peraturan tersebut merupakan alasan untuk memenuhi kebutuhan masyarakat yang menyangkut pada perkembangan permasalahan hukum pada saat itu. Karena selama ini banyak produk-produk hukum baik seperti undang-undang, peraturan pemerintah maupun peraturan daerah yang harus dibatalkan karena adanya penyimpangan substansi didalam peraturan tersebut dengan kenyataan yang ada. Peraturan seharusnya dibuat sesuai dengan kebutuhan masyarakat, tidak boleh menyimpang dan tidak boleh merugikan hak-hak dasar manusia termasuk hak asasi manusia, serta tidak boleh mengancam keselamatan jiwa manusia. Pembatalan Undang-Undang Nomor 22 Tahun 2014 tentang Pilkada yang didalamnya mengatur bahwa pemilihan kepala daerah dilakukan oleh $\mathrm{DPRD}^{26}$, alasan pembatan peraturan perundang-undangan tersebut karena adanya penyimpangan terhadap partisipasi publik dan Undang-Undang Dasar Negara Republik Indonesia Tahun 1945 yang menjelaskan bahwa Negara Republik Indonesia adalah negara demokrasi yang kedaulatan berada ditangan rakyat. Pemilihan yang dilakukan oleh DPRD tentu saja akan merampas hak warga negara untuk barpartisipasi dalam kontes demokrasi dan menggunakan hak pilihnya untuk memilih kepala daerah sesuai dengan kehendak hati nuraninya, sehingga dengan adanya pembatalan undang-undang tersebut dan menggantikan dengan undangundang yang baru dengan penetapan bahwa pemilu akan dilakukan secara langsung dengan memberikan kesempatan bagi masyarakat untuk ikut serta memberikan hak pilihnya di pilkada yang dilakukan di Indonesia.

25 Riris Katharina, 2017, Analisis Terhadap Masalah Pilkada di Papua, Jurnal Penelitian Politik dalam Negeri, Vol.9, No.6, hal 18

26 Jorawati Simarmata, 2015, Prespektif Kebiajakan Daerah dalam Konteks Undang-Undang Nomor 23 Tahun 2014 tentang Pemerintahan Daerah dan Peraturan Perundang-Undangan Terkait, e-jurnal. Peraturan.go.id, hal.15 
Pemilihan kepala daerah secara langsung dan serental pada saat wabah covid-19 ini, menimbulkan kebimbangan di pemerintahan karena keadaan virus berbahaya yang mengancam keselamatan jiwa masyarakat Indonesia. Dengan adanya peraturan perundangundangan Nomor 6 Tahun 2020 memberikan perlindungan bagi masyarakat pada saat pilkada ditengah pandemi ini,walaupun tidak ada yang menjamin bahwa tidak ada penyebaran dan lonjakan kasus positif saat pilkada walaupun sudah menerapkan protokol kesehatan yang ditentukan. Aspek tersebut jika dikaitkan dengan pemilihan kepala daerah yang ada di Indonesia, terlebih sekarang dilakukan secara serantak oleh seluruh daerah di Indonesia dalam prespektif sosiologi hukum, maka dapat melihat perubahan-perubahan hukum yang dipengaruhi oleh perubahan sosial yang terjadi dimasyarakat terlebih dalam masa pandemi virus covid-19. Peraturan hukum tersebut memberikan sebuah tanggapan atassegala gejolak yang terjadi dimasyarakat karena kekhawatiran akan terjadi penularan pada saat pemilihan kepala daerah, peraturan tersebut juga memberikan perlindungan atas keselamatan jiwa manusia agar tercipta suasana pilkada yang demokratis dan efektif.

Maka dari itu, untuk mengurangi segala gejolak yang ada di masyarakat selama proses pemilihan kepala daerah dimasa covid-19, diperlukan hukum dengan menghadirkan segala bentuk proses pemilihan yang efektif. Pemilihan umum yang efektif dapat dipengaruhi oleh undang-undang itu sendiri, yang mana undang-undang sebagai dasar pedoman dalam proses pemilihan sehingga segala sesuatunya harus diatur secara jelas termasuk gejolak sosial yang akan timbul selama proses pemihan kepala daerah. Sselain itu, mawas diri juga berpengaruh pada pemilihan yang efektif karena mawas diri merupakan bentuk untuk mengoreksi segala sesuatu yang ada di dalam diri sendiri secara jujur, sehingga akan tahu kelebihan dan kekurangan yang ada di dalam masing-masing individu. Sarana prasarana yang memadai juga berpengaruh untuk membentuk pemilihan kepala daerah yang efektif, karena tanpa sarana prasarana yang memadai segala proses pemilihan kepala daerah tidak akan berjalan dengan maksimal. Dan yang terakhir adalah masyarakat itu sendiri, sumber daya manusia sangat berpengaruh pada efektif atau tidaknya pilkada yang dilakukan. Seorang yang mempunyai sumber daya manusia yang baik maka akan dapat menentukan pilihan calon kepala daerah dengan menilai segala kapasitas yang ada didalam diri calon pasangan. Solusi lain yang ditawarkan adalah dengan cara memperkuat makna dari demokrasi itu sendiri secara lebih fleksibel karena mengingat Indonesia terdiri atas berbagai keragaman adat istiadat berbeda-beda yang dapat berpengaruh dalam sistem penyelenggaraan pemilu ${ }^{27}$, sesuai dengan amanat yang tercantum dalam konstitusi kita, Undang-Undang Dasar Negara Republik Indonesia Tahun 1945 Pasal 18B, bahwa Bangsa Indonesia mengakui satuan-satuan daerah yang bersifat khusus dan istimewa, sehingga segala peraturan mengenai pemilihan kepala daerah pada setiap daerah dapat ditentukan dengan sistem yang berbeda-beda sesuai dengan ciri khas daerah masing-masing.

\section{Kesimpulan}

Melihat proses pemilihan kepala daerah yang ada di Indonesia, sebelumnya dilakukan secara langsung. Namun, pada masa presiden Susilo Bambang Yudhoyono, calon kepala daerah dipilih langsung oleh DPRD. Karena banyaknya gejolak dimasyarakat, pada era Presiden Joko Widodo mengembalikan pemilihan kepala daerah kedalam demokrasi

27 Noor M. Aziz, 2009, Pengkajian Hukum Tentang Pemilihan Kepala Daerah, Laporan Akhir Badan Pembinaan Hukum Nasional Kementrian Hukum dan HAM RI, hal 119. 
pemilu, dimana calon pasangan kepala dan wakil kepala daerah dipilih secara langsung oleh rakyat. Walaupun banyak dampak positif dan negatif akibat pemilihan kepala daerah secara langsung, sebenarnya hal tersebut memberikan sebuah harapan bagi rakyat Indonesia demi mewujudkan kedaulatan rakyat karena rakyat dapat memilih secara langsung, sehingga akan memunculkan calon-calon kepala daerah yang berkualitas menurut rakyat Indonesia. Pemilihan kepala daerah yang dilakukan secara langsung juga memberikan peran penting bagi perkembangan disuatu daerah terutama demi mewujudkan keberhasilan otonomi daerah, dimana peran pemerintah terutama kepala daerah yang menjadi pokok pada sistem pemerintah daerah akan menjadi penentu untuk pembangunan dan kemajuan di daerahnya

Pilkada Tahun 2020 yang dilakukan secara serentak ditengah wabah covid 19 dan proses pemilihan kepala daerah yang sering dibarengi dengan segala konflik dan gejolak dimasyarakat karena disebabkan oleh beberapa faktor. Membutuhkan suatu pendekatan secara sosiologi demi memberikan pemecahan yang dinamis terhadap permasalahan atas konflik-konflik yang timbul dimasyarakat. Sosiologi hukum memandang bahwa pemilihan umum yang efektif dapat dipengaruhi oleh undang-undang itu sendiri, yang mana undangundang sebagai dasar pedoman dalam proses pemilihan sehingga segala sesuatunya harus diatur secara jelas termasuk gejolak sosial yang akan timbul selama proses pemihan kepala daerah. Untuk menjawab segala kegelisahan terhadap pemilihan kepala daerah pada saat masa pandemi, pemerintah menghadirkan Undang-Undang Nomor 6 Tahun 2020 demi memberikan jaminan keselamatan jiwa manusia dan demi terselenggaranya pesta demokrasi yang efektif berdasarkan Pancasila dan Undang-Undang Dasar Negara Republik Indonesia. Sehingga berbagai permasalahan hukum yang berkaitan dengan pilkada, maka yang harus diperbaiki bukan manusianya tetapi hukumnya karena hukum adalah untuk manusia, bukan manusia untuk hukum yang bertujuan demi tercapainya kehidupan yang sejahteran dan bahagia dimasyarakat.

\section{Daftar Pustaka}

Undang-Undang Dasar Negara Republik Indonesia Tahun 1945

Undang-Undang Nomor 9 Tahun 2015 tentang perubahan atas Undang-Undang 23 Tahun 2014 tentang Pemerintahan Daerah

Undang-Undang Nomor 6 Tahun 2020 tentang Penetapan Peraturan Perundang-Undangan Nomor 2 Tahun 2020 tentang Perbuahan Ketiga Undang-Undang Perundang-Undangan Nomor 10 Tahun 2016 tentang Perubahan Kedua atas Undang-Undang Nomor 1 Tahun 2015 tentang Pemilihan Gubernur, Bupati, dan Walikota

Putusan Mahkamah Konstitusi dalam Nomor 5/PUU-V/2007 perihal Pengujian UndangUndang Nomor 32 Tahun 2004 tentang Pemerintah Daerah

Amarudi dan A. Zaini Bisri, 2006, Pilkada Langsung : Problematika dan Prospek, Yogyakarta : Pustaka Pelajar.

Kacung Marijan, 2010, Sistem Politik Indonesia : Konsolidasi Demokrasi Pascra-Orde Baru, Jakarta : Kencana Predana Media Group. 
Komarudin Sahid, 2011, Memahami Sosiologi Politik, Bogor : Ghalia Indonesia.

Leo Agustino, 2009, Pilkada dan Dinamika Politik Lokal, Yogyakarta : Pustaka Pelajar.

R. Siti Zuhro,dkk, 2011, Model Demokrasi Lokal, Jakarta : PT. HTC Mandiri.

Saukani HR,dkk, 2002, Otonomi Daerah dalam Negara Kesatuan, Yogyakarta : Pustaka Pelajar.

Soerjono Soekanto, 1988, Pokok-Pokok Sosiologi Hukum,Jakarta : PT. Raja Grafindo Perkasa.

H. Djuari, 2011, Problematika Pemiliha Kepala Daerah Secara Langsung (dalam Prespektif Sosiologis), Jurnal Dinamika Hukum Unissula Semarang.

Jorawati Simarmata, 2015, Prespektif Kebiajakan Daerah dalam Konteks Undang-Undang Nomor 23 Tahun 2014 tentang Pemerintahan Daerah dan Peraturan PerundangUndangan Terkait, e-jurnal. Peraturan.go.id.

Nopyandari, 2011, Pemilihan Kepala Daerah yang Demokratis dalam Prespektif UndangUndang Dasar Negara Kesatuan Republik Indonesia Tahun 1945, Jurnal Ilmu Hukum, Vol. 1, No. 2

Retno Saraswati, 2011, Calon Perseorangan : Pergeseran Paradigma Kekuasaan dalam Pemilukada, Jurnal Masalah-Masalah Hukum.

Richard S. Katz and William, 2006, Handbook of Party Politics, London : Sage Publocations.

Marso, 2002, Susunan dalam Satu Naskah Undang-Undang Dasar Tahun 1945 dengan perubahan-perubahannya, Jakarta : Eko Jaya.

Ridho Imawan Hanafi, 2014, Pemilihan Langsung Kepala Daerah di Indonesia : Beberapa Catatan Kritis untuk Partai Politik, Jurnal Ilmu Politik Universitas Indonesia.

Riris Katharina, 2017, Analisis Terhadap Masalah Pilkada di Papua, Jurnal Penelitian Politik dalam Negeri, Vol.9, No.6.

Suyatno, 2016, Politik Indonesia, Jurnal Unnes, Vol. 1, No 2.

Suyatno, 2016, Pemilihan Kepala Daerah dan Tantangan Demokrasi Lokal di Indonesia, Jurnal Unnes Vol. 1 No. 2.

Syafri Hariansah, 2018, Analisis Pilkada dalam Prespektif Sosiologi Hukum, Tesis Program Pascasarjana Universitas Indonesia.

Teguh Imam Satiyono, 2020, Urgensi Perpu Pilkada di Masa Pandemi Covid-19, Webinar Nasional Forum Masyarakat, Universitas Widya Mataram

Teten Jamaludim, 2019, Pilkada Langsung : Kisah Sukses dan Problematika, Jurnal Politik Walisongo.

Edi Suwiknyo, 2020, 135 Calon Kepala Daerah Gugat Hasil Pilkada, KPU Perlu di evaluasi?, Bisnis.com, diakses pada 18 Desember 2020, pukul 17:00

Hadijah Alaydrus, 2020, Ini Catatan Terakhir Dana Pilkada 2020 dari Sri Mulyani, ekonomi. bisnis.com, diakses pada yanggal 28 Desember 2020, pukul 20:21 
Noor M. Aziz, 2009, Pengkajian Hukum Tentang Pemilihan Kepala Daerah, Laporan Akhir Badan Pembinaan Hukum Nasional Kementrian Hukum dan HAM RI.

Topan Yuniarto, 2020, Pilkada Langsung Serentak : Sejarah dan Perkembangannya di Indonesia, Kompas Pedia.

https://www.jogloabang.com/pustaka/uu-6-2020-perppu-2-2020-perubahan-ketiga-uu-1-2015pilkada-serentak, diakses pada 28 Desember 2020, pukul 21:23

https://www.bbc.com/indonesia/indonesia-55321183, diakses pada 28 Desember 2020, pukul $21: 33$ 